\title{
研究課題別事後評価結果
}

1. 研究課題名

完全フォトクロミック反応系の構築

2. 研究代表者名及び主たる研究参加者名（研究機関名・職名は研究参加期間終了時点）

研究代表者少江 正浩 九州大学大学院工学研究院 教授

主たる研究参加者 大須賀 篤弘 京都大学大学院理学研究科 教授( 平成 13 年 10 月)

板谷 明京都工芸繊維大学遷移学部 教授

植草 秀裕 東京工業大学大学院理工学研究科 助教授(平成 13 年 4 月 )

3. 研究内容及び成果

$3-1$ 研究の基本構想と展開

化学反応を制御して新規な物質を創るのではなく、完全制御可能な可逆光化学反応系を構築し、それらを新 規な光機能分子素子へ応用することを研究目標とした。

本プロジェクトでは、入江教授らが初めて合成・開発したフォトクロミックジアリールエテン分子群を対象 に、その極限性能（高効率性 : 主反応量子収率 $=1$ ，高選択性 : 副反応量子収率 $=0$ ）の達成をめざした。フ オトクロミック分子からなる分子材料は、分子一個の光応答が機能を支配するという特徵をもっており、従っ て分子一つ一つの光反応性を完全制御することが、そのまま材料の機能の制御につながる。

研究体制としては九大院工・入江正浩教授を研究代表者とし、京大院理・大須賀篤弘教授がポルフィリンと の連結によるスイッチ機能を、そして京都工䋊大・板谷明教授らが光反応の動力学、特に結晶内での転位反応 の解析を担当した。

ここで行った研究は大きく分類すると、以下のようになる。

(1) 光反応の高効率化の達成への試みージアリールエテン分子の化学修飾、包接による固定、オリゴマー 化による固定など

（2） 単結晶フォトクロミック反応と量子収率 1 の達成

（３）表面モルフォロジーの光変化の発掘

（4）分子内磁気相互作用の光制御

（5）単一分子の光メモリーへの端緒

またこれとは別に大須賀教授らによって、ポルフィリンアレー、ポルフィリンテープ等も見出された。

これらの研究は一個の分子が機能発現を起こし、それを産業に応用することを可能とする途を拓いたことに なる。

$3-2$ 研究成果

$3-2-1$ 光反応の高効率化の試み

ジアリールエテン分子そのものに様々の化学修飾をほどこすことを試みた。ジアリールエテンの開環体に は、2つのコンフォメーションが共存し、その内のパラレルコンフォーマーは光反応性をもたない。この割合 を減少させなければ、光反応効率は増大しない。嵩高い置換基を反応部位に導入することにより、パラレルコ ンフォメーションをとりにくくし、反応効率を増大させることができた。しかし、光反応量子収率は最大 0.8 程度までしか上昇しなかった。

また、ジアリールエテンをシクロデキストリンに包接させることにより、コンフォメーションを規制して、 光反応の高効率化を計ったが、0.5程度が最大であった。その他オリゴマー化も行ったがいずれも目標には達 しなかった。

$3-2-2$ 単結晶フォトクロミズム

いくつかのジアリールエテンが単結晶状態においてもフォトクロミック反応することを見出した。そのX線 構造解析を行った所、大部分のジアリールエテンが光反応性のアンチパラレルコンフォメーションで配置して いることが判明した。このことは、結晶中では高い反応効率で光反応がすすむことを示唆している。事実、 1 0 種類のジアリールエテン単結晶の光反応量子収率を測定すると、反応点間距離が $4.1 \AA$ 以下の場合、 1 （100\%）の值が得られた。完全光反応系が構築されたことになる。（特許出願） 


\section{$3-2-3$ 表面モルフォロジーの光変化}

単結晶において、構成単位である分子の分子体積が光反応により小さくなれば、そのことは結晶外形に影響 を及ぼすと考えられる。結晶表面モルフォロジーの光変化を原子間力顕微鏡により測定したところ、約 $1 \mathrm{~nm}$ のステップの光可逆形成が認められた。このナノメートルスケールの光変形は、ナノアクチュエーターへの応 用が期待される。(Science誌掲載)

\section{3-2-4 分子内磁気相互作用の光制御}

ジアリールエテンは、光閉環、開環反応に伴ってnー共役構造が変化する。両アリール基は、開環状態では ாー共役は連結されていないが、閉環状態になると連結されるようになる。このことから、ジアリールエテン ユニットは、 $ா$ ー共役連結を結合(ON)、切断(OFF)するスイッチとして機能する。チオフェンアリール基の両 端ヘスピンを導入し、分子内磁気相互作用を光制御することに成功した。（特許出願）

\section{$3-2-5$ 単一分子光メモリーの端緒}

蛍光強度がフォトクロミック反応により大きく変化する分子を合成し、単一分子蛍光のフォトクロミック反 応に伴うオン/オフ光スイッチの直接観測を試みた。その結果単一分子の蛍光のデジタルオン／オフ光スイッ チが観測された。（Nature誌掲載）

\section{3-2 - 6 レーザーフォトリシス法による光反応機構の解析（板谷グループ）}

ジアリールエテンの光閉環反応速度（光着色反応）は極端に速く、溶液中、結晶中いずれにおいても数ピコ 秒以内に起こる。この高速性が、フォトクロミック反応に対して酸素消光効果がなく、また繰り返し耐久性に 優れている原因であると考えられる。

\section{$3-2-7$ 縮環ポルフィリンの開発（大須賀グループ）}

ポルフィリンがメゾーメゾ結合して多数個連結した「ポルフィリンアレー」、縮環結合した「ポルフィリン テープ」が合成できた。縮環することにより、吸収スペクトルは長波長化し、赤外領域にまで電子遷移レベル の下がることが認められた。（特許出願 数件）

4. 事後評価結果

4-1. 外部発表(論文、口頭発表等)、特許、研究を通じての新たな知見の取得等の研究成果の状況

量子収率 1 (100\%) を目指した入江教授らの研究は結晶フォトクロミズムとして花が開いた。以下、特徵的 なものを示す。

$4-1-1$ 単結晶フォトクロミズム

(1) S.Kobatake,T.Yamada,K.Uchida,N.Kato,M.Irie,J.Am.Chem.Soc., $121,2380(1999)$

単結晶状態において、ジアリールエテンがフォトクロミック反応することを述べた最初のFull Paper.着 色閉環体が、結晶格子中において規則正しく配列していることを、 $X$ 線構造解析及び偏光スペクトル解 析から明らかにした。

4-1- 2 表面モルフォロジーの変化

(2) M.Irie,S.Kobatake,M.Horiuchi,Science,291,1651(2001)

結晶相における光反応で、表面においてステップが可逆的に生成した。ナノメートルスケールの変形は ナノアクチュエーターヘの応用が出来る。

$4-1$ - 3 単一分子フォトクロミズム

( 3 ) M.Irie,T.Fukaminato,T.Sasaki,N.Tamai,T.Kawai,Nature,420,759(2002)

フォトクロミック分子と蛍光性物質とをアダマンチルスペーサーで結合し、光照射することで蛍光の光 スイッチが観測された。単一分子系においてはじめての系である。

4-1-4 フォトクロミズムの応用

いろいろな応用が考えられているが、一つの例を示す。

( 4 ) S.Irie,T.Yamaguchi,H.Nakazumi,S.Kobatake,M.Irie,Bull.Chem.Soc.Jpn., 72,1139(1999)

ジチエニルエテン単結晶は、 $\mathrm{Y}$ 線などの高エネルギー放射線によっても着色することが見出された。この 
着色は、高感度でまた照射線量にたいして線形応答することから、カラー線量計へ応用可能であること が示唆された。

$4-2$. 得られた研究成果の科学技術への貢献

このグループで目標としていた量子収率 1 (100\%)、そして光劣化しないという極限性能をもつフォトクロ ミック反応系を単結晶という場で構築することが出来た。またこの結晶は光照射により表面モルフォロジーを ナノメートルレベルで可逆に変えるという機能を持っている。さらに分子一個でも機能発現出来て、それを計 測等に応用することが、蛍光スイッチング等で証明できた。これらは日本発の材料として学問的にも産業的に も展開する礎となっており、すでに応用技術も出はじめている。

2002年9月にドイツでジアリールエテン分子の研究者が一堂に会するシンポジウムが開かれたが、非常に好 評であった。

$4-3$. その他の特記事項

入江教授の研究は、従来は全く考えられなかった極めて高い性能のフォトクロミズムを示す

一群の物質の発見創製とその機能に関する、日本発の素晴らしい研究である。最終報告会における講演は基礎 的な研究から材料に至るまでの広範な内容が盛り込まれ、光化学関係の国際会議においても他を圧倒すると思 われる。また研究の波及効果も極めて大きく、ノーベル賞受賞者のJ.M.Lehnの研究室を始め、世界で十数力 国約 40 の研究室（企業も含む）が、この物質を使用して研究を進めている。この仕事のように純国産で、し かも海外でフォローしている研究について、我が国としての一層のサポートを期待したいものである。

$\leq<$ 単一分子トップ

This page updated on September 12, 2003

Copyright(C)2003 Japan Science and Technology_Corporation 